\title{
Quantification of DMS aerosol-cloud-climate interactions using the ECHAM5-HAMMOZ model in a current climate scenario
}

\author{
M. A. Thomas ${ }^{1}$, P. Suntharalingam ${ }^{1}$, L. Pozzoli ${ }^{2}$, S. Rast ${ }^{3}$, A. Devasthale ${ }^{4}$, S. Kloster ${ }^{5, *}$, J. Feichter ${ }^{3}$, and \\ T. M. Lenton ${ }^{1}$ \\ ${ }^{1}$ School of Environmental Sciences, University of East Anglia, Norwich, UK \\ ${ }^{2}$ Climate Change Unit, Joint Research Center, Italy \\ ${ }^{3}$ Max-Planck-Institute for Meteorology, Hamburg, Germany \\ ${ }^{4}$ Swedish Meteorological and Hydrological Institute, Norrkoping, Sweden \\ ${ }^{5}$ Earth and Atmospheric Sciences, Cornell University, Ithaca, NY, USA \\ *now at: Max Planck Institute for Meteorology, Hamburg, Germany
}

Received: 11 December 2009 - Published in Atmos. Chem. Phys. Discuss.: 5 February 2010

Revised: 16 July 2010 - Accepted: 21 July 2010 - Published: 10 August 2010

\begin{abstract}
The contribution of ocean dimethyl sulfide (DMS) emissions to changes in cloud microphysical properties is quantified seasonally and globally for present day climate conditions using an aerosol-chemistry-climate general circulation model, ECHAM5-HAMMOZ, coupled to a cloud microphysics scheme. We evaluate DMS aerosol-cloud-climate linkages over the southern oceans where anthropogenic influence is minimal. The changes in the number of activated particles, cloud droplet number concentration (CDNC), cloud droplet effective radius, cloud cover and the radiative forcing are examined by analyzing two simulations: a baseline simulation with ocean DMS emissions derived from a prescribed climatology and one in which the ocean DMS emissions are switched off. Our simulations show that the model realistically simulates the seasonality in the number of activated particles and CDNC, peaking during Southern Hemisphere ( $\mathrm{SH}$ ) summer coincident with increased phytoplankton blooms and gradually declining with a minimum in $\mathrm{SH}$ winter. In comparison to a simulation with no DMS, the CDNC level over the southern oceans is $128 \%$ larger in the baseline simulation averaged over the austral summer months. Our results also show an increased number of smaller sized cloud droplets during this period. We estimate a maximum decrease of up to $15-18 \%$ in the droplet radius and a mean increase in cloud cover by around $2.5 \%$ over the southern oceans during SH summer in the simulation with ocean DMS compared to when the DMS emissions are switched off. The global annual mean top of the atmo-
\end{abstract}

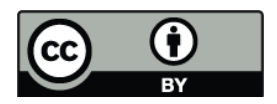

Correspondence to: M. A. Thomas (manu.thomas@uea.ac.uk) sphere DMS aerosol all sky radiative forcing is $-2.03 \mathrm{~W} / \mathrm{m}^{2}$, whereas, over the southern oceans during SH summer, the mean DMS aerosol radiative forcing reaches $-9.32 \mathrm{~W} / \mathrm{m}^{2}$.

\section{Introduction}

Research on phytoplankton induced dimethyl sulfide (DMS) emissions from the global oceans and their potential impact on the climate was stimulated by the publication of the CLAW hypothesis in 1987 (Charlson et al., 1987). This hypothesis suggested the linkages between the following processes:

1. In a warmer world enhanced phytoplankton blooms would result in increased ocean DMS concentrations and an increased flux of DMS to the atmosphere.

2. DMS is oxidized in the atmosphere and forms $\mathrm{SO}_{4}$ which nucleates or condenses on existing particles to form sulfate aerosols.

3. These aerosols have the capability to act as cloud condensation nuclei $(\mathrm{CCN})$ and an increase or decrease in their concentrations could modulate the planetary albedo thereby affecting the climate.

However, the exact contribution of the individual processes in this proposed feedback loop remains poorly characterized and therefore, our focus here is to separately quantify elements of the connecting links in this loop in a present day climate scenario.

A range of observational studies have explored the potential links between ocean DMS emissions and climate. Field studies investigating the links between DMS emissions and

Published by Copernicus Publications on behalf of the European Geosciences Union. 
CCN yield mixed conclusions (Hegg et al., 1991; Andreae et al., 1995; O'Dowd et al., 1997). One reason could be that the time scale of aerosol and CCN formation from DMS oxidation (several days to weeks) complicates the interpretation of the field measurements (Korhonen et al., 2008). A clearer relationship of the DMS-CCN link has been established from two marine measurement stations with long term $\mathrm{CCN}$ records, and from satellite sensors. Observations at Cape Grim, Tasmania (41 S) show similar seasonal cycles for atmospheric DMS and CCN concentrations; the CCN concentrations were 2-3 times higher in summer than in winter coinciding with the phytoplankton blooms in the summer (Ayers and Gras, 1991). Short-term airborne measurements close to the site indicate that $\mathrm{CCN}$ concentrations can be more than an order of magnitude higher in summer than in JJA (Yum and Hudson, 2004). These local observations are consistent with seasonal changes in cloud optical depth observed by satellite near Cape Grim (Boers et al., 1994). Measurements at the Mace Head Irish coastal site (53.19 N, $9.54 \mathrm{~W}$ ) indicated the highest $\mathrm{CCN}$ concentrations during the biologically productive season when the DMS emissions are expected to be high (Reade et al., 2006). This site, however, does not have continuous measurements of atmospheric DMS concentration, hence the DMS-CCN link could not be more clearly demonstrated over the seasonal cycle. Similar studies carried out over the Pacific ocean (1982-1985) also revealed that the area weighted concentrations were higher in summer than in winter (Bates et al., 1987) and that the changes in atmospheric and oceanic properties associated with El Nino events do not significantly affect the DMS sea water concentrations over the equatorial Pacific ocean $(15 \mathrm{~N}-$ 15 S) (Bates and Quinn, 1997). Studies using remote sensing data have also investigated the relationships between oceanic DMS and CCN. Vallina and Simo (2007) showed that DMS emissions can contribute to up to $30 \%$ of the globally averaged annual CCN column concentration, but, can be highly variable spatially. Meskhidze and Nenes (2006) using satellite data reported a good correlation between the chlorophyllA from SeaWiFS (Sea-viewing Wide Field-of-view Sensor) and CCN (positively correlated) and cloud droplet effective radii (negatively correlated) derived from MODIS (Moderate Resolution Imaging Spectroradiometer) over the 49 S-54 S latitude band. There is still uncertainty in the dependence of DMS flux on the chlorophyll-A concentration as only certain species of phytoplankton produce DMS. The study by Leck et al. (1990) revealed that the DMS concentration may be related to the phytoplankton growth under nitrogen limited conditions.

Modeling studies have also investigated the response of oceanic DMS sea surface concentration to changes in climate. Kloster et al. (2007) applied the ECHAM5 atmospheric model coupled to an ocean model and a marine biogeochemistry model in a transient climate simulation, and analyzed the changes in DMS sea surface concentrations induced by changes in climate. However, their study did not evaluate the DMS derived changes in the cloud microphysical properties. Gunson et al. (2006) evaluated the DMS$\mathrm{CCN}$-temperature link by using the Hadley Center coupled ocean atmosphere model, HADCM3. Their study quantified changes to cloud cover and cloud albedo for varying ocean DMS emissions, and reported global surface temperature changes of $-0.8^{\circ} \mathrm{K}$ and $+1.5^{\circ} \mathrm{K}$ for scenarios where DMS flux to the atmosphere is doubled and halved respectively. Korhonen et al. (2008) used an offline global atmospheric chemistry transport model with size resolved aerosol microphysics (GLOMAP-bin) to investigate the influence on $\mathrm{CCN}$ over the Southern Hemisphere ocean. They found a moderate contribution of DMS to regional CCN, smaller than that suggested by previous satellite data analysis. Their study also suggested that the main pathway of DMS influence on $\mathrm{CCN}$ number is nucleation of DMS derived $\mathrm{H}_{2} \mathrm{SO}_{4}$ in the free troposphere and subsequent growth by condensation and coagulation. A perturbed DMS patch in the southern oceans induces high CCN concentrations several thousand kilometers downwind of the patch due to the time scale (several days) of conversion from DMS into CCN (Woodhouse et al., 2008). Gondwe et al. (2003), using a global three dimensional chemistry transport model estimated the contribution of sea water DMS to the mean annual column burden of $\mathrm{nssSO}_{4}^{=}$(non sea salt sulfate) in the $\mathrm{SH}$ as $43 \%$, in comparison to the $\mathrm{NH}$ where it is only $9 \%$. Kloster et al. (2006) also obtained similar estimates with DMS derived $\mathrm{nsSOO}_{4}^{=}$contributions of $45 \%$ in the $\mathrm{SH}$ and $18 \%$ in the $\mathrm{NH}$.

The majority of these modeling studies report DMS derived influences as global mean values. They do not focus on the spatial and temporal variations of the cloud microphysical properties and climate or were unable to assess these changes in their model. In this study we use the state of the art aerosol-chemistry-climate general circulation model (GCM), ECHAM5-HAMMOZ to quantify the influence of oceanic DMS emissions on the individual processes and variables in the DMS-aerosol-cloud-climate loop proposed by CLAW. This study represents the first such model analysis to investigate the impact on cloud microphysics and climate using a GCM with coupled aerosol-chemistry. We evaluate the spatial and temporal distributions of the conversion of the ocean DMS to atmospheric $\mathrm{H}_{2} \mathrm{SO}_{4}$ concentrations in liquid phase. We also assess changes in the cloud microphysical properties, for example, changes in the cloud droplet concentration, cloud droplet radius and cloud cover, induced by changes in ocean DMS.

We focus, in particular, over the southern oceans during the SH summer months when DMS sea water concentrations are high (Kettle and Andreae, 2000; Kettle et al., 1999). Moreover, this remote marine lower troposphere is an ideal region for studying DMS-aerosol-cloud-climate interactions as it is region of abundant low level clouds and is relatively unaffected by anthropogenic emissions. 


\section{ECHAM5-HAMMOZ model, experimental set up and simulations}

The ECHAM5-HAMMOZ model used in the present study has three main components: the general circulation model, ECHAM5 (Roeckner and co authors, 2003), the tropospheric chemistry module, MOZ that is based on the chemical mechanism described by Horowitz et al. (2003) and the aerosol module, HAM (Hamburg Aerosol Model) (Stier et al., 2005). The ECHAM5 model is coupled to a detailed cloud microphysics module (Lohmann et al., 1999, 2007). A description of the respective modules is given in Pozzoli et al. (2008a). The chemistry and aerosol modules interact through three main mechanisms namely, photolytic reactions, sulfur chemistry and heterogeneous chemistry. The HAM module takes into account the major aerosol compounds: sulfate, black carbon, organic carbon, sea salt and mineral dust. The aerosol spectrum is represented by the combination of seven lognormal modes and these modes are described by the aerosol number, the number median radius and the standard deviation. Aerosols are categorized by size into nucleation, Aitken, accumulation and coarse modes. Mineral dust and sea salt emissions are calculated interactively following the parameterization schemes of Tegen et al. (2002) and Schulz et al. (2004), respectively. In the model, the sea salt source function is represented by the combination of the approach of Monahan et al. (1986) for small particle range and of Smith and Harrison (1998) for the coarse particle range. The MOZ chemical scheme is identical to the one used in the MOZART- 2 model and includes 63 tracers and 168 reactions to represent $\mathrm{O}_{\mathrm{x}}-\mathrm{NO}_{\mathrm{x}}$-hydrocarbon chemistry.

The pathway from DMS emissions to the cloud droplet formation in the model is shown schematically in Fig. 1. The DMS sea water concentrations are prescribed in the model from the climatology of Kettle and Andreae (2000). The DMS flux to the atmosphere is based on the parameterization of Nightingale et al. (2000). The MOZ component of the model considers two major reaction pathways for the conversion of atmospheric DMS to $\mathrm{SO}_{2}$ : 1. an abstraction pathway following a daytime reaction with $\mathrm{OH}$ and a nighttime reaction with $\mathrm{NO}_{3}$ and 2 . an addition pathway that leads to the formation of $75 \% \mathrm{SO}_{2}$ and $25 \%$ Methyl sulfonic acid (MSA) (Feichter et al., 1996). The $\mathrm{SO}_{2}$ is oxidized to $\mathrm{H}_{2} \mathrm{SO}_{4}$, whereas MSA is directly converted to $\mathrm{H}_{2} \mathrm{SO}_{4}$ in the gas phase. The conversion of $\mathrm{SO}_{2}$ in the gas phase to sulfate aerosol occurs via two mechanisms -1 . Homogeneous nucleation resulting in new particles by the condensation of $\mathrm{SO}_{2}$ in gas phase to sulfate aerosol and 2. Heterogeneous reaction involving the condensation of $\mathrm{SO}_{2}$ on to the surface of sea salt aerosols and mineral dust particles (Stier et al., 2005). The aqueous phase $\mathrm{SO}_{2}$ produces sulfate aerosol when oxidized by $\mathrm{O}_{3}$ and $\mathrm{H}_{2} \mathrm{O}_{2}$ ( $\mathrm{SO}_{2}$ in-cloud oxidation). Hence, the total aerosol sulfate production from $\mathrm{SO}_{2}$ is therefore limited by different factors, namely, availability of water, the oxidant concentrations $\left(\mathrm{OH}, \mathrm{O}_{3}, \mathrm{H}_{2} \mathrm{O}_{2}\right.$ and $\left.\mathrm{NO}_{3}\right)$. The cloud scheme

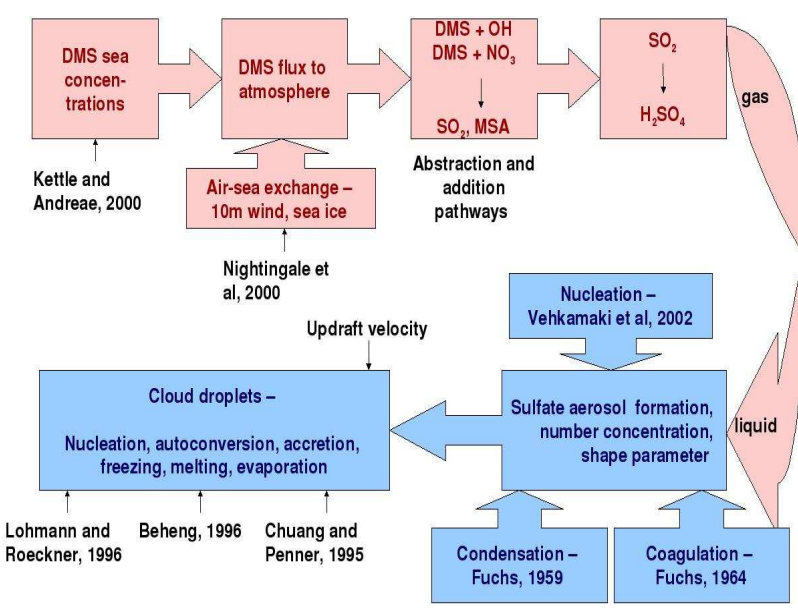

Fig. 1. Schematic showing the processes from DMS flux to the atmosphere to the cloud droplets as represented in the ECHAM5HAMMOZ model.

in the model is based on the modified version by Lohmann and Roeckner (1996). The number of cloud droplets is parameterized as a function of the total aerosol number concentrations, updraft velocity and a shape parameter that takes into account the aerosol composition and the size distribution.

Simulations are performed with a spectral resolution of T42 that corresponds to approximately $2.8 \times 2.8$ degrees horizontally, with 31 vertical levels from the surface up to $10 \mathrm{hPa}$ and with a 20-min time step. The model is driven by ECMWF ERA-40 meteorological fields (available every $6 \mathrm{~h}$ ) (Uppala et al., 2005). In this configuration, the prognostic variables of ECHAM5 (vorticity, divergence, temperature and surface pressure) are relaxed towards the ERA-40 reanalysis data (Machenhauer and Kirchner, 2000). To evaluate the influence of DMS emissions on aerosol formation, cloud properties and climate variables, we carry out two 1-year simulations from December 1999 to December 2000: [1] The baseline simulation with prescribed DMS sea water concentrations (CTRL); and [2] a simulation with no ocean DMS (wo_ODMS). Other emissions (anthropogenic and wildfire) of $\mathrm{SO}_{2}$, black carbon and organic carbon form the background aerosol concentrations, and are held fixed in our simulations in addition to the interactively computed sea salt and dust emissions. An 18-month spin up is conducted for these simulations. We analyze the differences between these two simulations (CTRL - wo_ODMS) to identify the influence of ocean DMS on tropospheric aerosols, cloud properties and climate, focussing in particular on the southern ocean latitudes. 

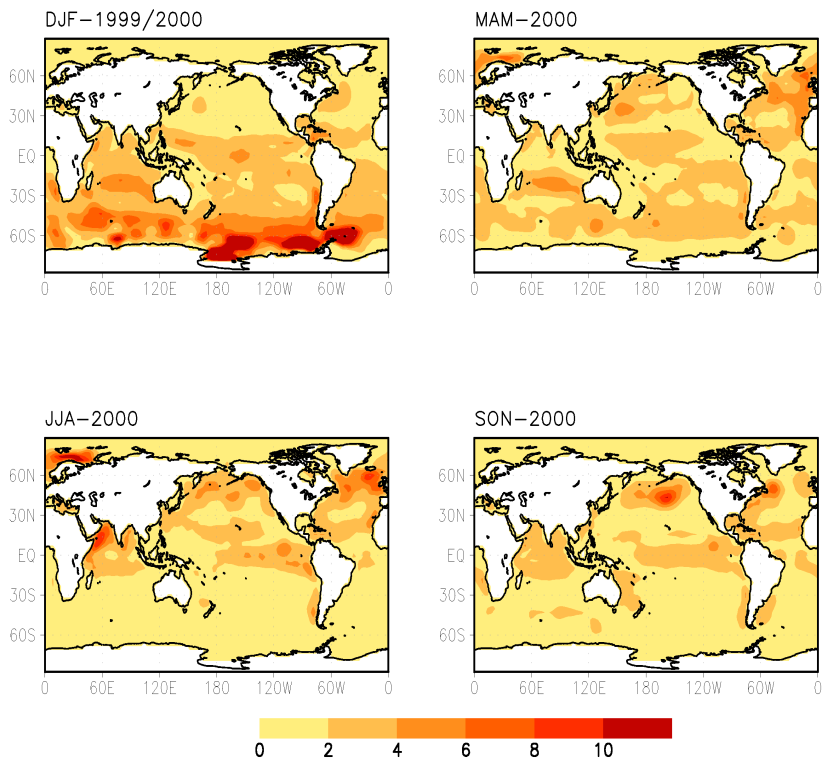

Fig. 2. Seasonal averages of ocean DMS emissions in $\mathrm{Kg}(\mathrm{S}) / \mathrm{m}^{2} / \mathrm{s}$ (multiplied by $10^{12}$ ).

\subsection{Model performance}

Model evaluation of individual components of ECHAM5HAMMOZ modules has been presented in several recent studies. The ECHAM5-HAM model has been comprehensively evaluated by Stier et al. (2005) who found good agreement between simulated and observed sulfate, black carbon and organic carbon surface concentrations regionally. The simulation of global annual mean aerosol optical depth agrees well with the MODIS satellite retrievals and with the AERONET ${ }^{1}$ measurements. Additionally, the cloud microphysics scheme in the ECHAM5-HAM model was validated by Lohmann et al. $(1999,2007)$ who found that the simulated mean liquid water path, column CDNC and effective radius agree well with satellite observations and the frequency distributions of column CDNC over oceans and the variations of cloud optical depth with effective radius are simulated realistically.

The ECHAM5-MOZ model was also assessed against observations by Rast et al. (2008), Pozzoli (2007) and Auvray et al. (2007), who noted that several characteristics of the tropospheric spatial and temporal distribution, such as seasonal cycles and latitudinal gradients, are captured by the model. The comparison of the ECHAM5-HAMMOZ model with TRACE-P ${ }^{2}$ aircraft campaign measurements showed that sulfate aerosol concentrations are generally well described in the north Pacific, but overestimated by a factor of 2 between $10 \mathrm{~N}$ and $25 \mathrm{~N}$. This is a region of high aerosol load-

\footnotetext{
${ }^{1}$ AERONET: AErosol RObotic NETwork

${ }^{2}$ TRACE-P: TRAnsport and Chemical Evolution over the Pacific
}

ing, where sulfate concentrations depend mainly on the continental outflow of $\mathrm{SO}_{2}$ and sulfate. The region under investigation in our study is a remote region in the high latitude $\mathrm{SH}$, where the sulfate concentrations are mainly dependent on DMS oxidation. The Northern Hemisphere sulfate concentration does not influence the values in our study region.

In general, a good agreement was found between modeled aerosol optical depth in Southern Hemisphere compared with satellite observations (Stier et al., 2005; Pozzoli et al., 2008b). The size distribution, number concentration and optical properties are reproduced well by the coupled model, though the agreement is better near the surface than in the upper troposphere, where the model underestimates these parameters. Pozzoli et al. (2008b) found that annual mean burdens for the aerosol species using ECHAM5-HAMMOZ model did not differ significantly from those found with ECHAM5-HAM by Stier et al. (2005). ECHAM5-HAMMOZ showed some regional improvements for sulfate, especially in comparison to the EMEP ${ }^{3}$ and IMPROVE ${ }^{4}$ observations over Europe and US, respectively. The improvements are very likely due to an improved representation of the $\mathrm{OH}$ concentrations in ECHAM5-HAMMOZ which calculates $\mathrm{OH}$ concentrations interactively, in comparison to the climatological values used in ECHAM5-HAM (Sect. 4 in the supplementary online material of Pozzoli et al. (2008b)).

\subsection{Comparison of ECHAM5-HAMMOZ baseline configuration with previous studies/satellite observations}

The DMS aerosol-cloud-climate simulation analyzed in this study has not been previously published. We therefore discuss the characteristics of this simulation here and compare to in-situ and satellite observations. Model variables evaluated include the simulated DMS flux to the atmosphere (Fig. 2), the tropospheric sulfate distribution (Fig. 3) and cloud properties namely, droplet radius and number concentrations and cloud liquid water path (Table 1). These are discussed in more detail below.

We first consider the simulated global annual mean DMS flux to the atmosphere. The model estimates a global annual DMS flux of $23.3 \mathrm{Tg}(\mathrm{S}) / \mathrm{yr}$ based on the gas exchange parameterization of Nightingale et al. (2000) and the Kettle and Andreae (2000) ocean DMS climatology. Other DMS flux estimates reported differ depending on the choice of the DMS sea surface climatology, gas exchange scheme and wind speed data; estimates vary from $16 \mathrm{Tg}(\mathrm{S}) / \mathrm{yr}$ to $54 \mathrm{Tg}(\mathrm{S}) / \mathrm{yr}$ (Kettle and Andreae, 2000). Our simulated global annual mean DMS flux is in close agreement with the findings of Boucher et al. (2003) who derived a global flux of

\footnotetext{
${ }^{3}$ EMEP: European Monitoring and Evaluation Programme

${ }^{4}$ IMPROVE: Interagency Monitoring of PROtected Visual Environments
} 
Table 1. Comparison of CD effective radii, CDNC and cloud liquid water path Cloud LWP) averaged over 30S-60S for DJF 1999/2000 from both model simulations and satellite observations. The HOAPS cloud liquid water path data are available only over ocean, hence, the averages are taken over ocean only.

\begin{tabular}{lcc}
\hline Parameters & Satellite data & Model \\
\hline CD effective radii $(\mu \mathrm{m})$ & 11.61 & 11.39 \\
CDNC $\left(1 / \mathrm{m}^{2}\right)$ & $3.4 \times 10^{10}$ & $4.4 \times 10^{10}$ \\
Cloud LWP $\left(\mathrm{kg} / \mathrm{m}^{2}\right)$ & 0.095 & 0.093 \\
\hline
\end{tabular}
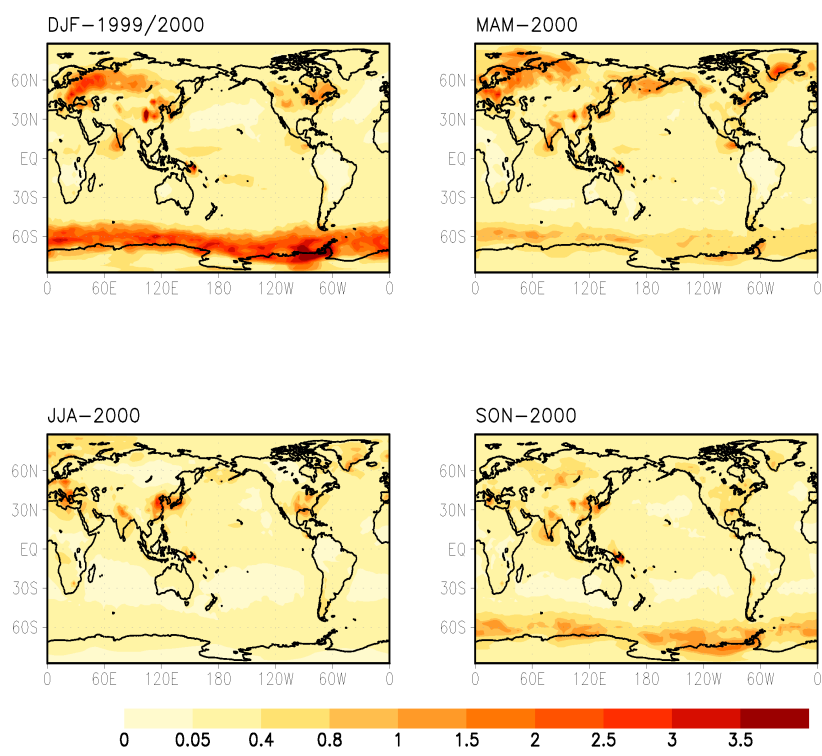

Fig. 3. Seasonal averages of $\mathrm{H}_{2} \mathrm{SO}_{4}$ concentrations in mass mixing ratios (MMR) at $850 \mathrm{hPa}$ (multiplied by $10^{12}$ ).

24-27 $\mathrm{Tg}(\mathrm{S}) / \mathrm{yr}$ based on the winds from the LMD-ZT general circulation model and the Nightingale et al. (2000) gas exchange.

Next, we compare the model generated seasonal cycle and magnitude of the ocean DMS flux to the atmosphere. Figure 2 presents the seasonal (three month averages) and spatial distribution of the DMS flux to the atmosphere in the baseline CTRL configuration (units of $\mathrm{Kg}(\mathrm{S}) / \mathrm{m}^{2} / \mathrm{s}$ ). We focus on the southern high latitudes from $30 \mathrm{~S}$ to $75 \mathrm{~S}$. The seasonal cycle of the DMS emissions is distinct peaking in SH summer months (Dec-Jan-Feb (DJF) 1999/2000) coinciding with the peak in ocean biological activity and gradually declining with a minimum averaged over June, July and August (JJA) (Boers et al., 1996, 1998; Ayers and Gillett, 2000). This seasonality is consistent with the temporal variation in chlorophyll concentrations derived from SeaWiFS (Meskhidze and Nenes, 2006) satellite data. Peak DMS fluxes exceed $10 \times 10^{-12} \mathrm{Kg}(\mathrm{S}) / \mathrm{m}^{2} / \mathrm{s}$ in localized high latitude regions during austral summer months (DJF 1999/2000) with a mean value of $4 \times 10^{-12} \mathrm{Kg}(\mathrm{S}) / \mathrm{m}^{2} / \mathrm{s}$ in the latitudi- nal belt of $30 \mathrm{~S}-75 \mathrm{~S}$. The mean winter fluxes are around $0.7 \times 10^{-12} \mathrm{Kg}(\mathrm{S}) / \mathrm{m}^{2} / \mathrm{s}$, almost one-eighth the mean summer fluxes in the southern belt $(30 \mathrm{~S}-75 \mathrm{~S})$.

The global seasonal distribution of the mass mixing ratios of atmospheric $\mathrm{H}_{2} \mathrm{SO}_{4}$ at $850 \mathrm{hPa}$ is shown in Fig. 3. Concentrations ranging from $1.5 \times 10^{-12}$ to as high as $3.0 \times 10^{-12}$ are simulated at $850 \mathrm{hPa}$ over the southern most latitude belt (60 S-75 S) during the SH summer months. The model produces a DJF mean concentration of $0.75 \times 10^{-12}$ whereas the JJA mean is $0.11^{*} 10^{-12}$ at $850 \mathrm{hPa}$ over the $30 \mathrm{~S}-75 \mathrm{~S}$ latitude belt. The seasonal variation in modelled $\mathrm{nssSO}_{4}=$ in our CTRL simulation is comparable to those of Gondwe et al. (2003) who used a 3D global chemistry transport model, TM3, to evaluate the contribution of ocean DMS emission to the column burden of $\mathrm{nssSO}_{4}=$. Their study find a 6-8 times increase in the DJF mean $\mathrm{nssSO}_{4}^{=}$compared to the JJA mean over the southern belt (30S-75S) which is comparable to our value of $\sim 7$.

The $\mathrm{H}_{2} \mathrm{SO}_{4}$ concentrations at $700 \mathrm{hPa}$ also follow the spatial distribution at $850 \mathrm{hPa}$ (Fig. S1 in the supplement). The concentrations at $700 \mathrm{hPa}$ in the Mar-Apr-May (MAM) seasonal mean is about half of the DJF seasonal mean. However, the $\mathrm{H}_{2} \mathrm{SO}_{4}$ concentrations during the $\mathrm{SH}$ autumnal months are higher at $700 \mathrm{hPa}$ than at $850 \mathrm{hPa}$.

Satellite sensors provide valuable information on cloud properties. Since the focus of this study is on aerosol cloud interactions over the southern oceans during austral summer, we compare three important model parameters in this context, namely, CDNC, cloud droplet (CD) effective radii and cloud liquid water path with satellite data. We use effective radii and cloud optical depth information from PATMOSx (AVHRR Pathfinder Atmospheres-Extended) to calculate adiabatic CDNC (Quaas et al., 2006). Additionally, we use cloud liquid water path from the most recent HOAPS (Hamburg Ocean Atmosphere Parameters and fluxes from Satellite data) (Andersson et al., 2007) Version-3 data set. These two data sets are available for the DJF 1999/2000 over the southern oceans in the latitudinal belt of 30S-60S, enabling comparison for the same time period with our model simulations.

Table 1 shows the comparison of satellite data with model estimates. The CD effective radii agree closely with satellite data over the southern oceans during austral summer, where the baseline model simulation estimates a mean droplet radius of $11.39 \mu \mathrm{m}$, compared to the mean satellite estimate of $11.61 \mu \mathrm{m}$. This is also consistent with the comparison reported by Lohmann et al. (1999) for ECHAM5. The agreement between simulated and satellite observations is also very good for cloud liquid water path. However, the model seems to overestimate the CDNC over the $30 \mathrm{~S}-60 \mathrm{~S}$ latitude belt in summer. In general, these three cloud properties are simulated realistically by ECHAM5-HAMMOZ for the $\mathrm{SH}$ high latitudes. 


\section{Results and discussion}

We now focus on the impact of ocean DMS on the cloud microphysics. For this, we analyze the CTRL and wo_ODMS simulations discussed in Sect. 2. Both the simulations are driven by same meteorological fields, so the differences in these runs (CTRL-wo_ODMS) are primarily due to the differences in the oceanic DMS emissions. The "simulated differences" are often defined as "anomalies" in this text.

\subsection{Spatial and seasonal variations in the cloud microphysical properties}

Here, we quantify the changes in the different processes outlined in Fig. 1 arising from the influence of DMS emissions. Gaseous phase $\mathrm{H}_{2} \mathrm{SO}_{4}$ is converted to sulfate particles, which in turn grows to cloud droplet size thereby modifying the cloud microphysical properties such as cloud droplet effective radii and the cloud cover. This will affect the atmospheric radiative forcing. The following sections discuss the DMS induced changes in the number of activated particles, CDNC, cloud droplet (CD) effective radii, cloud cover and the all sky radiative forcing at the top of the atmosphere in present day climate state.

\subsubsection{Activated particles, CDNC, CD effective radii and total cloud cover}

The number of particles available for activation to cloud droplets are termed activated particles and the change in the number of activated particles at $850 \mathrm{hPa}$ is presented in Fig. 4. The figures show an increase in the number of activated particles in the CTRL simulation compared to the wo_ODMS case, especially over the southern belt $(30 \mathrm{~S}-$ $75 \mathrm{~S}$ ) in the $\mathrm{SH}$ at $850 \mathrm{hPa}$ during DJF $1999 / 2000$ in the CTRL simulation compared to the wo_ODMS case. The maximum value of the anomalies is $2.7 \times 10^{8}$ per cubic meter over the $30 \mathrm{~S}-75 \mathrm{~S}$ latitudinal belt, with a mean value of $1.6 \times 10^{8}$ per cubic meter during the summer months. At $700 \mathrm{hPa}$, the activated particles are more prevalent in the $45 \mathrm{~S}-75 \mathrm{~S}$ belt (not shown here) with a maximum of up to $1.8 \times 10^{8}$ per cubic meter. A significant contribution of DMS to the activated particles is also seen in MAM months at $850 \mathrm{hPa}$ and is confined to a narrow belt around $30 \mathrm{~S}-45 \mathrm{~S}$, but, the amplitude is half that of the DJF values. The seasonal cycle and spatial distribution of the particles available for activation follows the DMS emissions cycle and seasonality with a maximum during the SH summer months, gradually decreasing with a minimum during the $\mathrm{SH}$ winter months.

Figure 5 represents the seasonally averaged DMS related anomalies in CDNC burden for the simulation period. The anomalies show a clear seasonal cycle with four times higher mean concentrations of the cloud droplets in summer (DJF) than in the winter (June-July-Aug). The DMS related changes vary from $4 \times 10^{10} 1 / \mathrm{m}^{2}$ in summer to $1 \times 10^{10} 1 / \mathrm{m}^{2}$
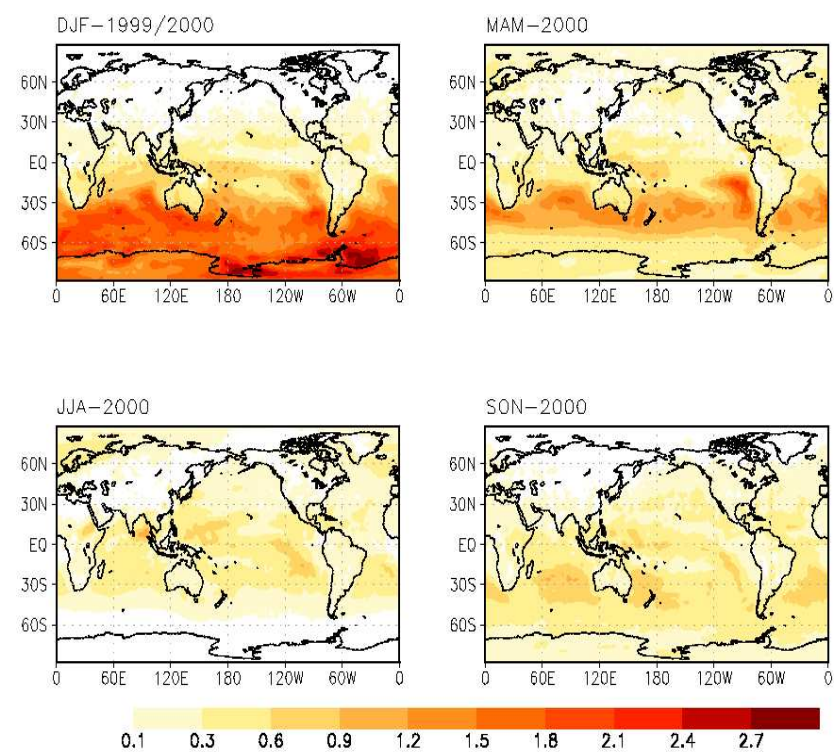

Fig. 4. Seasonal averages of changes in the number of activated particles at $850 \mathrm{hPa}\left(1 / \mathrm{m}^{3}\right)$ in the CTRL simulation compared to the wo_ODMS simulation (multiplied by $10^{-8}$ ). Positive values mean there is an increase in the number of activated particles in the simulation when the DMS sea water concentrations are present.

in winter over the latitude belt $30 \mathrm{~S}-75 \mathrm{~S}$. The zone of maximum CDNC anomaly is located in $40 \mathrm{~S}-75 \mathrm{~S}$ latitude belt in DJF and is shifted further north to $25 \mathrm{~S}-50 \mathrm{~S}$ in MAM months. The seasonal anomalies clearly follow the peak and variation of the ocean DMS emissions presented in Fig. 2.

Other sources of aerosols (in addition to DMS emissions) that may contribute to the modification of the microphysical properties of clouds over the southern oceans is sea salt aerosol and ocean derived organic particles. Studies have shown that these particles are a potential contributor to cloud condensation nuclei (Latham and Smith, 1990; Latham, 2002; Latham et al., 2008; Jones et al., 2009; O'Dowd et al., 2004; Gantt et al., 2009). However, as further discussed below, sea salt derived CD number concentrations are relatively small in the southern high latitudes suggesting that DMS is the major contributor to cloud condensation nuclei, particularly, over the southern oceans during austral summer months. In the current model version, we do not have an explicit treatment of marine organics.

The influence of ocean DMS emissions on the cloud top cloud droplet effective radius in microns is shown in Fig. 6. The effective radius is evaluated at the cloud top to facilitate comparison with the satellite data, that sees only the cloud top. This is computed from the difference between the two simulations (CTRL-wo_ODMS), and negative values, shown in blue, correspond to a decrease in the droplet radius with DMS generated sulfate aerosols in the atmosphere. There is a decrease in the droplet radius in summer (DJF) in the southern most latitude belt ( $30 \mathrm{~S}-75 \mathrm{~S}$ ) in comparison to the other 

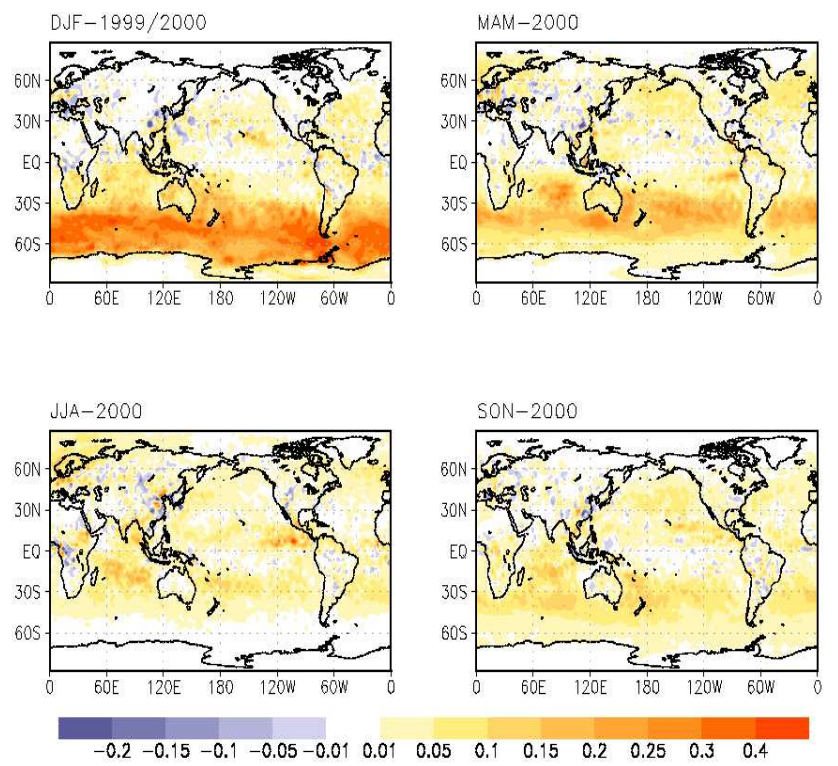

Fig. 5. Seasonal averages of changes in the vertically integrated cloud droplet number concentration (CDNC) $\left(1 / \mathrm{m}^{2}\right)$ in the CTRL simulation compared to the wo_ODMS simulation (multiplied by $10^{-11}$ ). Positive values mean there is an increase in CDNCs in the simulation when the DMS sea water concentrations are present.

regions. However, the decrease is not uniform along this belt and the values range from $0.5-2.0 \mu \mathrm{m}$, with a mean value of $0.73 \mu \mathrm{m}$. MODIS retrieved CD effective radii estimates show an average of $\sim 14 \mu \mathrm{m}$ outside the phytoplankton bloom with a sharp decrease (to $\sim 10 \mu \mathrm{m}$ ) in the vicinity of the bloom (Meskhidze and Nenes, 2006). These estimates were taken from the southern ocean of an area averaged over $55 \mathrm{~W}-21 \mathrm{~W}$ and $42 \mathrm{~S}-60 \mathrm{~S}$ and gridded to a resolution of $2^{\circ} \times 2^{\circ}$. This impact of DMS on cloud droplet effective radius is less prominent in the MAM months and is not seen in the other seasonal averages.

Increased number of small sized cloud droplets means less coalescence efficiency and hence, less precipitation thereby resulting in increased cloud lifetime (Albrecht, 1989; Ramaswamy et al., 2001; Lohmann and Feichter, 2005). This effect is also known as the cloud lifetime effect. The seasonally averaged anomalies of the total fraction covered by clouds is analyzed (Fig. S2 in the supplement). Positive values (in yellow) correspond to an increase in cloud cover in the CTRL simulation with DMS emissions. It is evident that there is an increase of the total cloud cover in the latitudinal band from $30 \mathrm{~S}-75 \mathrm{~S}$ in summer (DJF) of up to $6 \%$. This increase in cloud coverage is shifted further north in the MAM months in consistence with the DMS emissions and the changes in $\mathrm{CD}$ number concentrations. The change in cloud cover is negligible during the rest of the year over the southern belt in the SH.
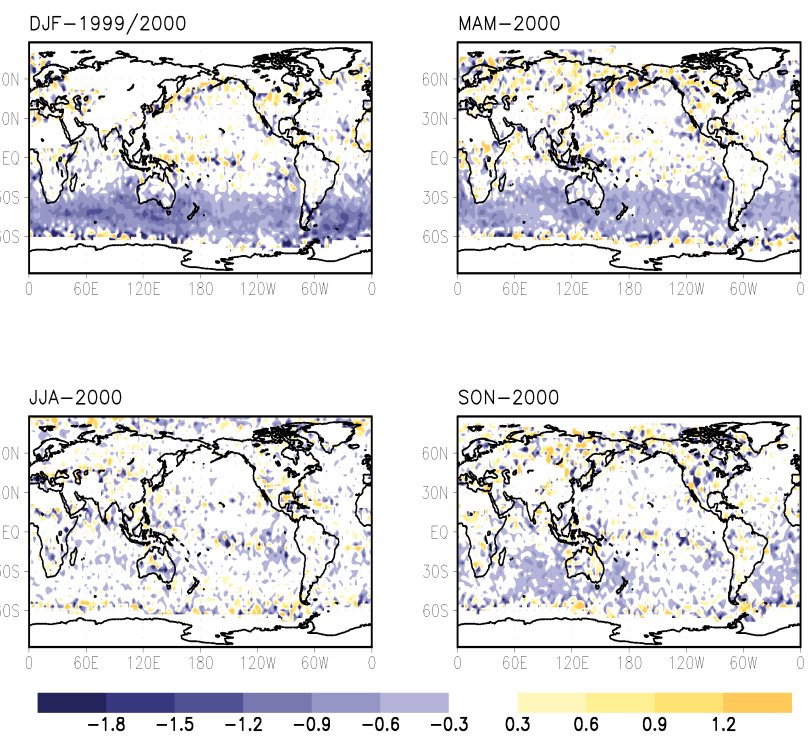

Fig. 6. Seasonal averages of changes in the cloud top cloud droplet effective radii $(\mu \mathrm{m})$ in the CTRL simulation compared to the wo_ODMS simulation. Negative values mean there is a decrease in $\mathrm{CD}$ radius in the simulation when the DMS sea water concentrations are present.
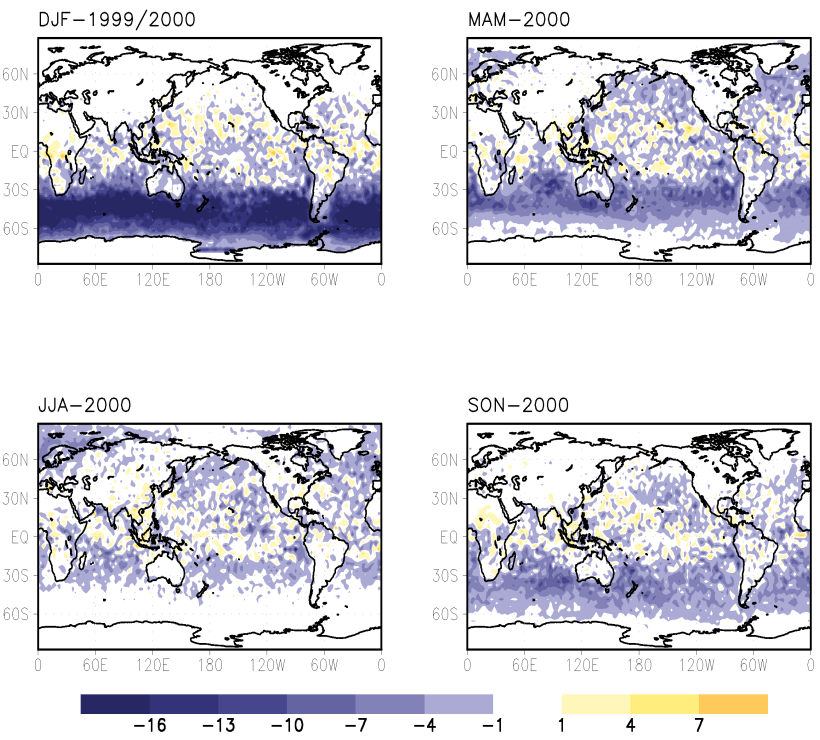

Fig. 7. Seasonal averages of total sky aerosol radiative forcing at the TOA $\left(\mathrm{W} / \mathrm{m}^{2}\right)$. Negative aerosol radiative forcing means there is a net cooling at the TOA.

\subsection{Aerosol radiative forcing at the top of the atmosphere}

Aerosol radiative forcing is a perturbation evaluated as a difference between perturbed and unperturbed values of the radiative fluxes caused by aerosols calculated under the same meteorological conditions. Here, we evaluate the impact 
of the DMS induced changes at the top of the atmosphere $(10 \mathrm{hPa})$. The radiative forcing is calculated as the difference between the net radiative flux at the TOA in the CTRL simulation and that in the wo_ODMS simulation under the same meteorological conditions. The large scale meteorology is constrained by nudging the fields to ERA40 reanalysis data, however, the small scale processes such as the aerosol-cloud feedback mechanisms are enabled, thereby not strictly abiding by the definition of radiative forcing mentioned in IPCC (Forster et al., 2007). The global annual mean DMS related aerosol radiative forcing at the TOA in our model simulations is estimated as $-2.03 \mathrm{~W} / \mathrm{m}^{2}$. We are not aware of other studies evaluating this quantity, however, Gunson et al. (2006) evaluated the aerosol radiative forcing for doubling and halving ocean DMS scenarios as a difference of the radiative flux perturbation of the two DMS scenarios from their control simulation which included the present day ocean DMS. They obtained values of $2.0 \mathrm{~W} / \mathrm{m}^{2}$ and $-3.0 \mathrm{~W} / \mathrm{m}^{2}$ respectively.

The seasonal distribution of combined (shortwave+longwave) radiative forcing under all sky conditions is presented in Fig. 7. During the $\mathrm{SH}$ summer months (DJF), the radiative forcing is significantly lower reaching a minimum value of $-16 \mathrm{~W} / \mathrm{m}^{2}$ in the $30 \mathrm{~S}-75 \mathrm{~S}$ latitudinal belt coinciding with the increased DMS emissions during these months. The simulated changes in the TOA radiative forcing are consistent with those calculated from satellite data presented in Meskhidze and Nenes (2006) where very strong cooling reaching $-15 \mathrm{~W} / \mathrm{m}^{2}$ is estimated in the biologically active regions in the southern oceans. The mean TOA aerosol radiative over the southern oceans in $\mathrm{SH}$ summer reaches $-9.32 \mathrm{~W} / \mathrm{m}^{2}$. The region of strong cooling (maximum negative radiative forcing belt) is shifted further north to $25 \mathrm{~S}-50 \mathrm{~S}$ latitude belt during SH spring and autumn where values range from -1 to $-7 \mathrm{~W} / \mathrm{m}^{2}$. The forcing is less than $-1 \mathrm{~W} / \mathrm{m}^{2}$ in $\mathrm{SH}$ winter.

\subsection{Temporal variability in cloud microphysical properties}

Here, we quantify the contribution of DMS to the changes in the cloud microphysical properties over the southern oceans. We consider three Southern Hemisphere latitudinal bands to facilitate comparison with the study by Korhonen et al. (2008): 30S-45S, 45S-60S, 60S-75S. The DMS derived changes in the number of activated particles and CDNC burden in these latitudinal bands are presented in Figs. 8 and 9, respectively.

Figure 8 shows the temporal distribution of the number of activated aerosol particles at $850 \mathrm{hPa}$ per cubic meter in the three latitude bands. The seasonal variation in the CTRL run (black line) that includes the DMS emissions is simulated in consistence with the ocean DMS seasonal cycle in all the 3 latitude bands with a maximum during the SH summer months and a minimum during the $\mathrm{SH}$ winter. The magnitude is two times higher than in the wo_ODMS simulation (red line), especially over the SH summer months. This implies that the DMS derived activated particles are significantly higher in the $45 \mathrm{~S}-75 \mathrm{~S}$ latitude belt during these months of the year compared to particles derived from other sources. However, there is a slight increase in the number of activated aerosol particles northward of $45 \mathrm{~S}$ in the wo_ODMS run which may be due to the particles from other sources.

Zonally averaged time series of the simulated CDNC burden for the three latitude bands are presented in Fig. 9. The black line and the red line show the absolute values of the cloud droplet concentrations in the CTRL simulation and the wo_ODMS simulation respectively. The seasonal variation in the vertically integrated $\mathrm{CD}$ number concentrations is evident south of $45 \mathrm{~S}$ in the CTRL simulation (black line). As in the case of Fig. 8, the CDNC burden in the wo_ODMS run (red line) also does not show a seasonal variation, but, remains constant at around $0.2 \times 10^{11} 1 / \mathrm{m}^{2}$ in the $30 \mathrm{~S}-60 \mathrm{~S}$ and around $0.1 \times 10^{11} 1 / \mathrm{m}^{2}$ beyond $60 \mathrm{~S}$. The amplitude is twice as high in the CTRL simulation in comparison to the wo_ODMS run during the summer in the $30 \mathrm{~S}-75 \mathrm{~S}$ latitude belt. The CDNC burden reaches as high as $0.6 \times 10^{11} 1 / \mathrm{m}^{2}$ during the austral summer months coinciding with the intense biological productivity during this season.

Here, as a cautionary note, we would like to point out that the previous studies have shown that the inclusion of ultrafine $(<0.1 \mu \mathrm{m})$ sea salt particles can have an impact on the number of activated particles and CDNC concentrations over the remote oceanic areas (Pierce and Adams (2006) and references therein). As mentioned in the previous section, in the ECHAM5-HAMMOZ model, to parameterize sea salt emissions, we use the Monahan et al. (1986) scheme (for particles in the range 0.1 to $10 \mu \mathrm{m}$ ) and Smith and Harrison (1998) scheme (for the coarse particle range). We therefore miss the influence of ultrafine emissions on the total CDNC burden. This might be one of the reasons why we underestimate the sea salt emissions in the wo_ODMS simulation.

The DMS derived contribution to the CDNC burden in the three latitude belts averaged over the austral summer months is presented in Table 4 as percentage deviations with respect to the wo_ODMS simulation. Our study shows an increase in the number of cloud droplets when ocean DMS is included. The mean increase in CDNC burden is $128 \%$ in the CTRL simulations when averaged over the DJF months in the $30 \mathrm{~S}-75 \mathrm{~S}$ latitude belt. The maximum increase is seen in the southern most belt $(60 \mathrm{~S}-75 \mathrm{~S})$ in the $\mathrm{SH}$, where the mean CDNC burden increases by $176 \%$ with respect to the simulation when the ocean DMS is switched off. More than $100 \%$ increase in the CDNCs are seen in the $45 \mathrm{~S}-60 \mathrm{~S}$ belt and the percentage increase is comparatively lower (89\%) in the $30 \mathrm{~S}-45 \mathrm{~S}$ belt. We compare our results to the study of Korhonen et al. (2008) who used an offline global chemistry transport model to evaluate the DMS contribution to cloud condensation nuclei in a similar experimental set up. Their simulation obtained a $46 \%$ increase in the CCN burden in January in the 30S-45S belt which is lower compared 

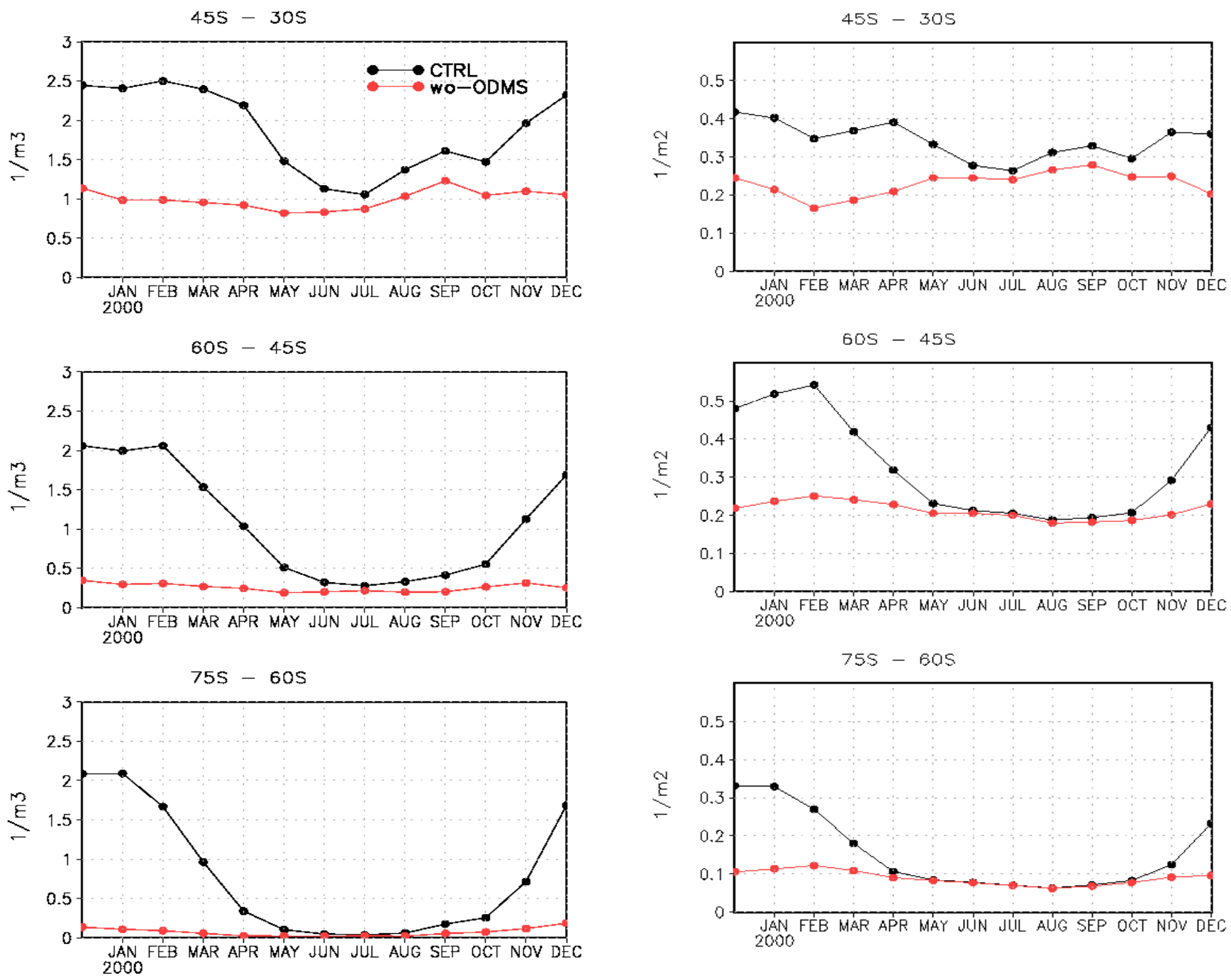

Fig. 8. Latitudinally averaged time series (December 1999December 2000) of the number of activated particles at $850 \mathrm{hPa}$ $\left(1 / \mathrm{m}^{3}\right)$ (multiplied by $10^{-8}$ ) shown as absolute values in (a) CTRL simulation denoted by the black line (b) wo_ODMS simulation denoted by the blue line.

to our results. However, the percentage changes in the latitudinal belt $45 \mathrm{~S}-75 \mathrm{~S}$ is even smaller $(11-18 \%$ at $45 \mathrm{~S}-60 \mathrm{~S}$ and $40 \%$ at $60 \mathrm{~S}-75 \mathrm{~S}$ ) in the study of Korhonen et al. (2008) compared to our results. They attribute this to the high sea spray contribution to $\mathrm{CCN}$ at these latitudes in their model and also, to the entrainment of the $\mathrm{CCN}$ into the marine boundary layer from the summer time free troposphere from distant continental sources when the ocean DMS is switched off. Meskhidze and Nenes (2006) estimated the monthly averaged CDNC outside the bloom and compared them with that inside the phytoplankton bloom area $(48 \mathrm{~S}-56 \mathrm{~S})$ in the southern oceans and showed that the cloud droplet number was doubled.

Fig. 9. Latitudinally averaged time series (December 1999December 2000) of the CDNC burden $\left(1 / \mathrm{m}^{2}\right)$ (multiplied by $10^{-11}$ ) shown as absolute values in (a) CTRL simulation denoted by the black line (b) wo_ODMS simulation denoted by the blue line.

The changes in the $\mathrm{CD}$ effective radii in percentage due to the DMS perturbation are presented in Table 2 for the $\mathrm{SH}$ summer months. The percentage differences show negative values during the SH summer months, meaning smaller droplet size in the CTRL simulation in comparison to the wo_ODMS experiment. This may be due to the fact that in the CTRL simulation, we have more aerosols competing for the available water vapour that is a constant in both the simulations, thereby resulting in a decrease in the droplet size compared to when the DMS derived aerosols are not present. The droplet radius is smaller by up to $7.4 \%$ in the southern most belt in the SH and by about $6.5 \%$ north of $60 \mathrm{~S}$ during DJF 1999/2000. The mean decrease in the droplet radius is $6 \%$ when averaged over the $30 \mathrm{~S}-75 \mathrm{~S}$ latitude belt in austral summer. Analysis of the satellite data indicates a decrease of $20-25 \%$ in the cloud droplet radius inside the phytoplankton 
Table 2. Percentage mean change (calculated as [(CTRLwo_ODMS)/wo_ODMS]*100) in the zonally averaged CDNC burden over the given latitudinal belts for the period December 1999March 2000.

\begin{tabular}{lcccc}
\hline Lat. $\Downarrow / /$ Mon. $\Rightarrow$ & December & January & February & March \\
\hline 45 S-30 S & 70.2 & 87.8 & 109.6 & 97.3 \\
60 S-45 S & 119.6 & 118.9 & 116.2 & 73.6 \\
75 S-60 S & 214.7 & 191.2 & 120.8 & 65.3 \\
\hline
\end{tabular}

Table 3. Percentage mean change (calculated as [(CTRLwo_ODMS)/wo_ODMS $\left.]^{*} 100\right)$ in the zonally averaged cloud top cloud droplet effective radii over the given latitudinal belts for the period December 1999-March 2000.

\begin{tabular}{lcccc}
\hline Lat. $\Downarrow / /$ Mon. $\Rightarrow$ & December & January & February & March \\
\hline 45 S-30 S & -5.81 & -6.07 & -6.41 & -5.90 \\
60 S-45 S & -6.78 & -6.00 & -6.15 & -5.63 \\
75 S-60 S & -7.44 & -5.14 & -3.78 & -1.10 \\
\hline
\end{tabular}

bloom regions in the southern oceans (Meskhidze and Nenes, 2006). The maximum decrease observed in our simulations over the southern oceans is $15-18 \%$.

The DMS induced contribution to cloud cover is presented in Table 3. Cloud cover is greater in the CTRL simulation in comparison to the wo_ODMS run in the three SH latitude bands during the austral summer. The mean total cloud cover increases by $3.5 \%$ in the northern most belt ( $30 \mathrm{~S}-45 \mathrm{~S})$, and by approximately $1.7 \%$ in the latitudinal belts south of $45 \mathrm{~S}$.

\subsection{DMS-sea salt interactions}

Sea salt can also be a contributor to $\mathrm{CCN}$ production (O'Dowd et al., 1999a,b), and here we address DMS-sea salt interactions in the context of our model study.

a) Previous studies show that $\mathrm{SO}_{2}$ can condense upon existing particles, such as sea salt (Cainey and Harvey, 2002). Bates et al. (1992) showed that a considerable fraction of non sea salt sulfate condenses on sea salt particles when the rate of photochemical $\mathrm{H}_{2} \mathrm{SO}_{4}$ production is low and when there is an abundance of large sea salt particles. Sea salt aerosol droplets facilitate the aqueous production of sulfate through the oxidation of $\mathrm{SO}_{2}$ by ozone; however, this fraction depends on the availability of ozone and unactivated sea salt aerosols (O'Dowd et al., 1997b). The reaction of ozone with $\mathrm{SO}_{2}$ on sea salt reduces the possibility of DMS derived sulfate to be a source of new CCN (von Glasow and Crutzen, 2004). However, over the southern ocean, sea salt emissions show very weak seasonal variability compared to biogenic emissions that show strong seasonality due to increased biological productivity in the austral summer (Vallina et al., 2006). This is reflected in Figs. 8 and 9 that show the number
Table 4. Percentage mean change (calculated as [(CTRLwo_ODMS)/wo_ODMS]*100) in the zonally averaged total cloud cover over the given latitudinal belts for the period December 1999March 2000.

\begin{tabular}{lcccc}
\hline Lat. $\Downarrow / /$ Mon. $\Rightarrow$ & December & January & February & March \\
\hline 45 S-30 S & 2.70 & 3.41 & 4.23 & 4.20 \\
60 S-45 S & 1.88 & 2.19 & 1.91 & 1.50 \\
75 S-60 S & 1.55 & 1.19 & 1.26 & 1.04 \\
\hline
\end{tabular}

of activated particles at $850 \mathrm{hPa}$ and CDNC burden respectively, indicating that the contribution from other particles (such as, sea salt) is negligible and also, by a weak seasonality in the wo_ODMS simulation. Since the heterogeneous reaction of $\mathrm{SO}_{2}$ on sea salt does not result in new particle formation, such strong seasonality in the figures could only be explained by the driving role of DMS derived $\mathrm{SO}_{2}$. Previous studies also indicate that DMS derived $\mathrm{CCN}$ dominate the total CCN concentrations in the southern ocean during austral summer (Ayers et al., 1997; Gras, 1989; Ayers and Cainey, 2007; Bates et al., 1987). While pointing out the importance of cloud frequency and semi-empirical parameters $\left(\mathrm{H}_{2} \mathrm{SO}_{4}\right.$ nucleation rate and accommodation coefficient), Pandis et al. (1994) and Russell et al. (1994) further show that under low DMS emissions (as in the case of austral winter), the DMS$\mathrm{CCN}$ link is non-linear due to heterogeneous reactions on sea salt; the link is likely to be linear in austral summer.

b) The sulfate burden over the southern ocean is the net result of the following processes. The heterogeneous reactions of $\mathrm{SO}_{2}$ on sea salt lead to a decrease of $\mathrm{SO}_{2}$. At the same time, the set of heterogeneous reactions in particular, the $\mathrm{N}_{2} \mathrm{O}_{5}$ reactions on wet particles lead to the reduction of $\mathrm{OH}$ (Pozzoli et al., 2008a). This in turn results in a decrease in $\mathrm{H}_{2} \mathrm{SO}_{4}$ production and subsequent sulfate production by condensation on existing particles. Using the same model configuration as used in the present study, Pozzoli et al. (2008b) on the other hand estimated that the $\mathrm{SO}_{2}$ incloud oxidation is the leading process for sulfate formation contributing about $57 \%$ to the total burden, thereby pointing to the secondary role of heterogeneous reactions on sea salt.

c) Measurements at Cape Grim indicate that DMS may not be the primary factor controlling the $\mathrm{CCN}$ numbers in the marine boundary layer (MBL), however, measurements in the free troposphere (FT) indicate that DMS and DMS derived $\mathrm{SO}_{2}$ can play a role in the $\mathrm{CCN}$ production in the FT which would subsequently be entrained in to the MBL (Ayers and Cainey, 2007; Cainey and Harvey, 2002; Raes, 1995; Shaw et al., 1998). The heterogeneous reactions would most likely dominate in the clean MBL (Ayers et al., 1997; Cainey and Harvey, 2002) whereas in the FT, $\mathrm{SO}_{2}$ concentrations required to support new particle formation via homogeneous nucleation (Mari et al., 1999; Cainey and Harvey, 2002) and in-cloud oxidation (Pozzoli et al., 2008b) are much higher 
compared to concentrations in the MBL. Since the changes in cloud microphysical properties discussed in the present study mainly occur above the MBL (with cloud liquid water content peaking around $850 \mathrm{hPa}$; not shown here), it is most likely that $\mathrm{CCN}$ at these levels are DMS derived. The ultrafine sea salt emissions can reach higher levels potentially interacting with DMS derived $\mathrm{SO}_{2}$, but, as mentioned in Sect. 3.3, such emissions are not included in the model version used here.

In view of the issues discussed above, we conclude that the DMS-sea salt interactions have a relatively minor influence on the results presented here.

\section{Conclusions}

In this paper we quantify the DMS derived changes in the cloud microphysical properties. These changes are evaluated over the southern oceans (30 S-75 S) where anthropogenic effects are minimal. Our main focus is during the austral summer, when the DMS flux to the atmosphere is high. We also present the spatial and seasonal averages for the rest of the year. To assess this, the state of the art, ECHAM5-HAMMOZ general circulation model that has a detailed aerosol module coupled to detailed chemistry and cloud microphysics modules is used. Two experiments are carried out: 1. A baseline simulation that includes the ocean DMS emissions (CTRL) and 2. A simulation in which the ocean DMS emissions are turned off (wo_ODMS). The difference between these two simulations represents the contribution from the ocean DMS emissions.

The main findings of our simulations are summarized below:

1. Our simulations show a clear seasonality in the variation in DMS derived aerosol particles over the southern oceans which mirror the changes in biological activity over the year consistent with the earlier studies by Boers et al. (1996, 1998); Ayers and Gillett (2000); Meskhidze and Nenes (2006).

2. The simulated global annual mean DMS flux to the atmosphere is $23.3 \mathrm{Tg}(\mathrm{S}) / \mathrm{yr}$, is in good agreement with Boucher et al. (2003) study based on similar parameterization scheme.

3. The DMS derived CDNC contributes to about $128 \%$ averaged over the $30 \mathrm{~S}-75 \mathrm{~S}$ latitude belt during the SH summer months. However, this estimate is overestimated when compared to the CCN burden estimates by Korhonen et al. (2008). Over the 30 S-75 S latitudinal belt, the CTRL simulation demonstrates seasonality in DMS derived CDNC with a maximum during austral summer and a minimum during the winter, whereas the simulated CDNC in the wo_ODMS experiment do not show this seasonality.

4. The evaluation of the wo_ODMS simulation in the northern most latitude belt (30 S-45 S) analyzed in this study indicates the presence of CDNC derived from other sources such as, sea salt, but is negligible compared to the DMS contribution to CDNC, particularly, in SH summer.

5. Our simulations also reproduce an increased number of smaller sized cloud droplets during austral summer and autumn in the 30S-60S latitude band. Vertically integrated atmospheric water vapour is held constant in the two simulations, thus, this is a demonstration of the first aerosol indirect effect. The maximum decrease in our model derived droplet radius is $15-18 \%$ compared to the $20-25 \%$ decrease estimated from MODIS derived estimates published in Meskhidze and Nenes (2006).

6. DMS emissions increase the simulated cloud cover by about $3.5 \%$ in the $30 \mathrm{~S}-45 \mathrm{~S}$ belt, by around $1.7 \%$ in the $45 \mathrm{~S}-75 \mathrm{~S}$ belt during the SH summer months.

7. The radiative forcing due to DMS derived sulfate aerosols reaches a minimum value of $-16 \mathrm{~W} / \mathrm{m}^{2}$ in the $30 \mathrm{~S}$ $75 \mathrm{~S}$ latitude belt in the DJF averages. This is in agreement with Meskhidze and Nenes (2006) study where strong cooling reaching $-15 \mathrm{~W} / \mathrm{m}^{2}$ in the biologically productive regions is found. The global annual mean indirect aerosol radiative forcing due to DMS is $-2.03 \mathrm{~W} / \mathrm{m}^{2}$.

The CLAW hypothesis was postulated as a fundamental climate feedback. However, the research since then has helped us understand the complexities in the different processes involved and the difficulties in assessing the strength of the feedback. Uncertainties still exist in the quantification of the influence of DMS on climate in a future climate scenario. Recent works (Yoon and Brimblecombe, 2002; Pierce and Adams, 2006; Smith, 2007) have shown that the sea salt aerosols play a role in marine $\mathrm{CCN}$ production. Further improvements are needeed to include sea salt in a wide range of size distribution realistically to quantify the role of DMS-sea salt interactions in global climate models. Also, the role of marine organic aerosol in $\mathrm{CCN}$ formation needs more investigation and may be important as indicated by some studies (O’Dowd et al., 2004; Gantt et al., 2009; Russell et al., 2010). Further research is required to quantify the relative roles of these particles in marine $\mathrm{CCN}$ production over the southern oceans.

Acknowledgements. This work was supported and funded by the QUEST-feedbacks project under the UK Natural Environment Research Council (NERC) QUEST programme. We acknowledge the availability of HOAPS-3 data from the World Data Center for Climate at DKRZ, Hamburg, Germany. AD would like to thank Andrew Heidinger (NOAA/NESDIS) for providing PATMOS-x data.

Edited by: L. M. Russell 


\section{References}

Albrecht, B.: Aerosols, Cloud Microphysics, and Fractional Cloudiness, Science, 245, 1227-1230, 1989.

Andersson, A., Bakan, S., Karsten, F., Grassl, H., Klepp, C.-P., and Schulz, J.: Hamburg Ocean Atmosphere Parameters and Fluxes from Satellite Data - HOAPS-3-monthly mean, World Data Center for Climate, 2007.

Andreae, M. O., Wolfgang, E., and de Mora, S.: Biogenic sulfur emissions and aerosols over the tropical South Atlantic 3. Atmospheric dimethylsulfide, aerosols and cloud condensation nuclei, J. Geophys. Res., 100, 11335-11356, 1995.

Auvray, M., Bey, I., Llull, E., Schultz, M. G., and Rast, S.: A model investigation of tropospheric ozone chemical tendencies in long-range transported pollution plumes, J. Geophys. Res., 112, D05304, doi:10.1029/2006JD007137, 2007.

Ayers, G. and Gras, J.: Seasonal relationships between cloud condensation nuclei and aerosol methane sulphonate in marine air, Nature, 353, 834-835, 1991.

Ayers, G. P. and Cainey, J. M.: The CLAW hypothesis: a review of the major developments, Environ. Chem., 4, 366-374, 2007.

Ayers, G. P. and Gillett, R. W.: DMS and its oxidation products in the remote marine atmosphere: implications for climate and atmospheric chemistry, J. Sea Res., 43, 275-286, 2000.

Ayers, G. P., Cainey, J. M., Gillett, R. W., and Ivey, J. P.: Atmospheric sulphur and cloud condensation nuclei in marine air in the southern hemisphere, Phil. Trans. R. Soc. Lond. B. Biol. Sci., 352, 203-211, 1997.

Bates, T., Cline, J. D., Gammon, R. H., and Kelly-Hansen, S. R.: Regional and seasonal variations in the flux of oceanic dimethylsulfide to the atmosphere, J. Geophys. Res., 92, 2930-2938, 1987.

Bates, T. S. and Quinn, P. K.: Dimethylsulfide (DMS) in the equatorial Pacific Ocean (1982 to 1996): Evidence of a climate feedback?, Geophys. Res. Lett., 24, 861-864, 1997.

Bates, T. S., Calhoun, J. A., and Quinn, P. K.: Variations in the methanesulfonate to sulfate molar ratio in submicrometre marine aerosol particles over the Pacific Ocean, J. Geophys. Res., 97, 9859-9865, 1992.

Boers, R., Ayers, G., and Gras, J.: Coherence between seasonal variation in satellite-derived cloud optical depth and boundary layer CCN concentrations at a mid-latitude Southern Hemisphere station, Tellus, 46B, 123-131, 1994.

Boers, R., Jensen, J. B., Krummel, P. B., and Gerber, H.: Microphysical and short-wave radiative structure of wintertime stratocumulus clouds over the Southern Ocean, Q. J. Roy. Meteorol. Soc., 122, 1307-1339, 1996.

Boers, R., Jensen, J. B., and Krummel, P. B.: Microphysical and short-wave radiative structure of stratocumulus clouds over the Southern Ocean: Summer results and seasonal differences, Q. J. Roy. Meteorol. Soc., 124, 151-168, 1998.

Boucher, O., Moulin, C., Belviso, S., Aumont, O., Bopp, L., Cosme, E., von Kuhlmann, R., Lawrence, M. G. ., Pham, M., Reddy, M. S., Sciare2, J., and Venkataraman, C.: DMS atmospheric concentrations and sulphate aerosol indirect radiative forcing: a sensitivity study to the D MS source representation and oxidation, Atmos. Chem. Phys., 3, 49-65, doi:10.5194/acp-3-49-2003, 2003.

Cainey, J. M. and Harvey, M. J.: Dimethylsulfide, a limited contributor to new particle formation in the clean marine boundary layer,
Geophys. Res. Lett., 29, 1128, doi:10.1029/2001GL014439, 2002.

Charlson, R. J., Lovelock, J. E., Andreae, M. O., and Warren, S. G.: Oceanic phytoplankton, atmospheric sulphur, cloud albedo and climate., Nature, 326, 655-661, 1987.

Feichter, J., Kjellstrom, E., Rodhe, H., Dentener, F., Lelieveld, J., and Roelofs, G.: Simulation of the tropospheric sulfur cycle in a global climate model, Atmos. Environ., 30, 1693-1707, 1996.

Forster, P., Ramaswamy, V., Artaxo, P., Berntsen, T., Betts, R., Fahey, D., Haywood, J., Lean, J., Lowe, D., Myhre, G., Nganga, J., Prinn, R., Raga, G., Schulz, M., and Dorland, R. V.: Changes in Atmospheric Constituents and in Radiative Forcing, in: Climate Change 2007: The Physical Science Basis. Contribution of Working Group I to the Fourth Assessment Report of the Intergovernmental Panel on Climate Change, edited by: Solomon, S., Qin, D., Manning, M., Chen, Z., Marquis, M., Averyt, K. B., Tignor, M., and Miller, H. L., Cambridge University Press, Cambridge, UK, and New York, NY, USA, 2007.

Gantt, B., Meskhidze, N., and Kamykowski, D.: A new physically-based quantification of marine isoprene and primary organic aerosol emissions, Atmos. Chem. Phys., 9, 4915-4927, doi:10.5194/acp-9-4915-2009, 2009.

Gondwe, M., Krol, M., Gieskes, W., Klaassen, W., and de Baar, H.: The contribution of ocean-leaving DMS to the global atmospheric burdens of DMS, MSA, $\mathrm{SO}_{2}$, and $\mathrm{nssSO}_{4}=$, Global Biogeochem. Cy., 17(2), 1056, doi:10.1029/2002GB001937, 2003.

Gras, J. L.: Baseline atmospheric condensation nuclei at Cape Grim, J. Atmos. Chem., 11, 89-106, 1989.

Gunson, J. R., Spall, S. A., Anderson, T. R., Jones, A., Totterdell, I. J., and Woodage, M. J.: Climate sensitivity to ocean dimethylsulphide emissions, Geophys. Res. Lett., 33, 2006.

Hegg, D., Radke, L., and Hobbs, P.: Measurements of Aitken nuclei and cloud condensation nuclei in the marine atmosphere and their relationship to the DMS-cloudclimate hypothesis, J. Geophys. Res., 96, 18727-18733, 1991.

Horowitz, L. W., Walters, S., Mauzerall, D. L., Emmons, L. K., Rasch, P. J., Granier, C., Tie, X., Lamarque, J., Schultz, M. G., Tyndall, G. S., Orlando, J. J., and Brasseur, G. P.: A global simulation of tropospheric ozone and related tracers: Description and evaluation of MOZART, version 2, J. Geophys. Res., 108(D24), 2003.

Jones, A., Haywood, J., and Boucher, O.: Climate impacts of geoengineering marine stratocumulus clouds, J. Geophys. Res., 114, D10106, doi:10.1029/2008JD011450, 2009.

Kettle, A. and Andreae, M.: Flux of dimethylsulfide from the oceans: A comparison of updated data sets and flux models, J. Geophys. Res., 105, 26793-26808, 2000.

Kettle, A. J., Andreae, M. . O., Amourou, D., Andreae, T. W., Bates, T. S., Berresheim, H., ingemer, H. B., Boniforti, R., Curran, M., DiTullio, G. R., Helas, G., Jones, G. B., Keller, M. D., Kiene, R. P., Leck, C., Levasseur, M., Malin, G., Maspero, M., Matrai, P., McTaggart, A. R., Mihalopoulos, N., Nguyen, B., Novo, A., J.P.Putaud, Rapsomanikis, S., Roberts, G., Schebeske, G., Sharma, S., Simo, R., Staubes, R., Turner, S., and Uher, G.: A global database of sea surface dimethylsulfide (DMS) measurements and a procedure to predict sea surface D MS as a function of latitude, longitude, and month, Global Biogeochem. Cy., 13, 399-444, 1999.

Kloster, S., Feichter, J., Maier-Reimer, E., Six, K. D., Stier, P., and 
Wetzel, P.: DMS cycle in the marine ocean-atmosphere system a global model study, Biogeosciences, 3, 29-51, doi:10.5194/bg3-29-2006, 2006.

Kloster, S., Feichter, J., Maier-Reimer, E., Roeckner, E., Stier, P., Wetzel, P., Six, K. D., and Esch, M.: Response of DMS in the ocean and atmosphere to global warming, J. Geophys. Res.Biogeosci., 142(112), G03005, doi:10.1029/2006JG000224, 2007.

Korhonen, H., Carslaw, K., Spracklen, D., Mann, G., and Woodhouse, M.: Influence of oceanic DMS emissions on CCN concentrations and seasonality over the remote southern hemisphere oceans: A global model study, J. Geophys. Res., 113, D15204, doi:10.1029/2007JD009718, 2008.

Latham, J.: Amelioration of global warming by controlled enhancement of the albedo and longevity of low-level maritime clouds, Atmos. Sci. Lett., 3, 52-58, 2002.

Latham, J. and Smith, M.: Effect on global warming of winddependent aerosol generation at the ocean surface, Nature, 347, 372-373, 1990.

Latham, J., Rasch, P., Chen, C., Kettles, L., Gadian, A., Gettelman, A., Morrison, H., Bower, K., and Choularton, T.: Global temperature stabilization via controlled albedo enhancement of lowlevel maritime clouds, Phil. Trans. Roy. Soc. A, 366, 3969-3987, 2008.

Leck, C., Larsson, U., Baegander, L. E., Johansson, S., and Hajdu, S.: DimethylSulfide in the Baltic Sea: Annual variability in relation to biological activity, J. Geophys. Res., 95, 3353-3363, 1990.

Lohmann, U. and Feichter, J.: Global indirect aerosol effects: A review, Atmos. Chem. Phys., 5, 715-737, doi:10.5194/acp-5-7152005, 2005.

Lohmann, U. and Roeckner, E.: Design and performance of a new cloud microphysics scheme developed for the ECHAM general circulation model, Clim. Dynam., 12(8), 557-572, 1996.

Lohmann, U., Feichter, J., Chuang, C. C., and Penner, J. E.: Predicting the number of cloud droplets in the ECHAM GCM, J. Geophys. Res., 104, 9169-9198, 1999.

Lohmann, U., Stier, P., Hoose, C., Ferrachat, S., Roeckner, E., and Zhang, J.: Cloud microphysics and aerosol indirect effects in the global climate model ECHAM5-HAM, Atmos. Chem. Phys., 7, 3425-3446, doi:10.5194/acp-7-3425-2007, 2007.

Machenhauer, B. and Kirchner, I.: Diagnosis of systematic initial tendency errors in the ECHAM AGCM using slow normal mode data assimilation of ECMWF reanalysis data, CLIVAR Exchanges, 5, 9-10, 2000.

Mari, C., Suhre, K., Rosset, R., Bates, T. S., Huebert, B. J., Bandy, A. R., Thornton, D. C., and Businger, S.: One-dimensional modeling of sulfur species during the First Aerosol Characterization Experiment (ACE-1), J. Geophys. Res., 104, 21733-21749, 1999.

Meskhidze, N. and Nenes, A.: Phytoplankton and cloudiness in the Southern Ocean, Science, 314, 1419-1423, 2006.

Monahan, E., Spiel, D., and Davidson, K.: Oceanic whitecaps and their role in air-sea exchange, chapter: A model of marine aerosols generation via whitecaps and wave disruption, D. Reidel, Norwell, Massachusetts, 252 ed., 167-174, 1986.

Nightingale, P. D., Malin, G., Law, C. S., Liss, A. J. W. P. S., Liddicoat, M. I., Boutin, J., and Upstill-Goddard, R. C.: In situ evaluation of air-sea gas exchange parameterizations using novel con- servative and volatile tracers, Global Biogeochem. Cy., 14, 373$388,2000$.

O’Dowd, C., Facchini, M., Cavalli, F., Ceburnis, D., Mircea, M., Decesari, S., Fuzzi, S., Yoon, Y., and Putaud, J.: Biogenicallydriven organic contribution to marine aerosol, Nature, 431, 676680, 2004.

O’Dowd, C. D., Lowe, J. A., Smith, M. H., Davison, B., Hewitt, C. N., and Harrison, R. M.: Biogenic sulphur emissions and inferred non-sea-salt-sulphate cloud condensation nuclei in and around Antarctica, J. Geophys. Res., 102(D11), 12839-12854, 1997.

O’Dowd, C. D., H., S. M., E., C. I., and A., L. J.: Marine aerosol, sea-salt, and the marine sulphur cycle - A short review, Atmos. Environ., 31, 73-80, 1997b.

O'Dowd, C. D., Lowe, J. A., Smith, M. H., and Kaye, A. D.: The relative importance of non-sea-salt sulphate and sea-salt aerosol to the marine cloud condensation nuclei population: An improved multi-component aerosol-cloud droplet parameterization, Q. J. Roy. Meteorol. Soc., 125, 1295-1313, 1999a.

O'Dowd, C. D., Lowe, J. A., and Smith, M. H.: Coupling seasalt and sulphate interactions and its impact on cloud droplets concentration predictions, Geophys. Res. Lett., 26, 1311-1314, $1999 b$.

Pandis, S. N., Russell, L. M., and Seinfeld, J. H.: The relationship between DMS flux and CCN concentrations in remote marine regions, J. Geophys. Res., 99, 16945-16957, 1994.

Pierce, J. R. and Adams, P. J.: Global evaluation of CCN formation by direct emission of sea salt and growth of ultrafine sea salt, J. Geophys. Res., 111, D06203, doi:10.1029/2005JD006186, 2006.

Pozzoli, L.: Climate and chemistry interactions: Develpoment and evaluation of a coupled chemistry-aerosol-climate model, Ph.D. thesis, Ecole Polytech. Fed. de Lausanne, Lausanne, Switzerland, 2007.

Pozzoli, L., Bey, I., Rast, J. S., Schultz, M. G., Stier, P., and Feichter, J.: Trace gas and aerosol interactions in the fully coupled model of aerosol-chemistry-climate ECHAM5HAMMOZ: 1. Model description and insights from the spring 2001 TRACE-P experiment, J. Geophys. Res., 113, D07308, doi:10.1029/2007JD009007, 2008a.

Pozzoli, L., Bey, I., Rast, J. S., Schultz, M. G., Stier, P., and Feichter, J.: Trace gas and aerosol interactions in the fully coupled model of aerosol-chemistry-climate ECHAM5HAMMOZ: 2. Impact of heterogeneous chemistry on the global aerosol distributions, J. Geophys. Res., 113, D07309, doi:10.1029/2007JD009008, 2008b.

Quaas, J., Boucher, O., and Lohmann, U.: Constraining the total aerosol indirect effect in the LMDZ and ECHAM4 GCMs using MODIS satellite data, Atmos. Chem. Phys., 6, 947-955, doi:10.5194/acp-6-947-2006, 2006.

Raes, F.: Entrainment of free tropospheric aerosols as a regulating mechanism for cloud condensation nuclei in the remote marine boundary layer, J. Geophys. Res., 100, 2893-2903, 1995.

Ramaswamy, V., Boucher, O., Haigh, J., Hauglustaine, D., Haywood, J., Myhre, G., Nakajima, T., Shi, G. Y., and Solomon, S.: Radiative Forcing of Climate Change, in Climate Change 2001: The Scientific Basis, Contribution of working group I to the Third Assessment Report of the Intergovernmental Panel on Climate Change, edited by: Houghton, J. T., Ding, Y., Griggs, D. J., Noguer, M., van der Linden, P. J., Dai, X., Maskell, K. and 
Johnson, C. A., Cambridge University Press, New York, USA, 349-416, 2001.

Rast, S., Schultz, M. G., Bey, I., van Noije, T., Aghedo, A. M., Brasseur, G. P., Diehl, T., Esch, M., Ganzeveld, L., Kirchner, I., Kornblueh, L., Rhodin, A., Roeckner, E., Schmidt, H., Schroeder, S., Schulzweida, U., Stier, P., Thomas, K., and Walters, S.: Evaluation of the tropospheric chemistry general circulation model ECHAM5-MOZ and its application to the analysis of interannual variability in tropospheric ozone from 1960-2000, J. Geophys. Res., under review, 2008.

Reade, L., Jennings, S. G., and McSweeney, G.: Cloud condensation nuclei measurements at Mace Head, Ireland, over the period 1994-2002, Atmos. Res., 82, 610-621, 2006.

Roeckner, E., Bäuml, G., Bonaventura, L., Brokopf, R., Esch, M., Giorgetta, M., Hagemann, S., Kirchner, I., Kornblueh, L., Manzini, E., Rhodin, A., Schlese, U., Schulzweida, U., and Tompkins, A.: The atmospheric general circulation model ECHAM5. PART I: Model description,, MPI-Report, 349, 127 pp., 2003.

Russell, L. M., Pandis, S. N., and Seinfeld, J. H.: Aerosol production and growth in the marine boundary layer, J. Geophys. Res., 99, 20,989-21,003, 1994.

Russell, L. M., Hawkins, L. N., Frossard, A. A., Quinn, P. K., and Bates, T. S.: Carbohydrate-like composition of submicron atmospheric particles and their production from ocean bubble bursting, Proc. Natl. Acad. Sci., 107, 6652-6657, 2010.

Schulz, M., de Leeuw, G., and Balkanski, Y.: Sea-salt aerosol source functions and emissions, in Emissions of Atmospheric Trace Compounds, Springer, New York, USA, 333-359, 2004.

Shaw, G. E., Benner, R. L., Cantrell, W., and Clarke, A. D.: On the regulation of climate: a sulphate particle feedback loop involving deep convection, Clim. Change, 39, 23-33, 1998.

Smith, M. and Harrison, N.: The sea spray generation function, J. Aerosol Sci., 29, 189-190, 1998.

Smith, M. H.: Sea-salt particles and the CLAW hypothesis, Environ. Chem., 4(6), 391-395, 2007.

Stier, P., Feichter, J., Kinne, S., Kloster, S., Vignati, E., Wilson, J., Ganzeveld, T., Tegen, I., Werner, M., Balkanski, Y., Schulz, M., Boucher, O., Minikin, A., and Petzold, A.: The aerosolclimate model ECHAM5-HAM, Atmos. Chem. Phys. 5, 11251165, doi:10.5194/acp-5-1125-2005, 2005.
Tegen, I., Harrison, S. P., Kohfeld, K., I. C. Prentice, M. C., and Heimann, M.: Impact of vegetation and preferential source areas on global dust aerosol: Results from a model study, J. Geophys. Res., 107(D21), 4576, doi:10.1029/2001JD000963, 2002.

Uppala, S., Kallberg, P., Simmons, A., Andrae, U., da Costa Bechtold, V., Fiorino, M., Gibson, J., Haseler, J., Hernandez, A., Kelly, G., Li, X., Onogi, K., Saarinen, S., Sokka, N., Allan, R. P., Andersson, E., Arpe, K., Balmaseda, M., Beljaars, A., van de Berg, L., Bidlot, J., Bormann, N. ., Caires, S., Chevallier, F., Dethof, A., Dragosavac, M., Fisher, M., Fuentes, M., nn, S. H., Holm, E., Hoskins, B., Isaksen, L., Janssen, P., Jenne, R., McNally, A. P., Mahfouf, J.-F., Morcrette, J.-J., Rayner, N., Saunders, R., Simon, P., Sterl, A., Trenberth, K. E., Untch, A., Vasiljevic, D., Viterbo, P., and Woollen, J.: The ERA-40 re-analysis, Q. J. Roy. Meteorol. Soc., 131, 2961-3012, 2005.

Vallina, S. M. and Simo, R.: Strong relationship between DMS and the solar radiation dose over the global surface ocean, Science, 315, 506-508, 2007.

Vallina, S. M., Simo, R., and Gasso, S.: What controls CCN seasonality in the Southern Ocean? A statistical analysis based on satellite-derived chlorophyll and $\mathrm{CCN}$ and model estimated $\mathrm{OH}$ radical and rainfall, Global Biogeochem. Cy., 20, GB1014, doi:10.1029/2005GB002597, 2006.

von Glasow, R. and Crutzen, P.: Model study of multiphase DMS oxidation with a focus on halogens, Atmos. Chem. Phys., 4, 589608, doi:10.5194/acp-4-589-2004, 2004.

Woodhouse, M. T., Mann, G. W., Carslaw, K. S., and Boucher, O.: New Directions: The impact of oceanic iron fertilisation on cloud condensation nuclei, Atmos. Environ., 42, 5728-5730, 2008.

Yoon, Y. J. and Brimblecombe, P.: Modelling the contribution of sea salt and dimethyl sulfide derived aerosol to marine CCN, Atmos. Chem. Phys., 2, 17-30, doi:10.5194/acp-2-17-2002, 2002.

Yum, S. S. and Hudson, J. G.: Wintertime/summertime contrasts of cloud condensation nuclei and cloud microphysics over the Southern Ocean, J. Geophys. Res., 109, D06204, doi:10.1029/2003JD003864, 2004. 